Tyndale Bulletin 65.1 (2014) 141-152

\title{
VERY EARLY TRINITARIAN EXPRESSIONS
}

\author{
Stuart E. Parsons
}

\begin{abstract}
Summary
While older scholarship identified the earliest use of Trinitarian terminology near the end of the second century in the work of Theophilus of Antioch, some recent studies have challenged this view. However, while affirming certain insights of these newer studies, it is necessary to revisit them in light of the historical setting of the secondcentury apologists. In reality, Theophilus and other early apologists evidenced a certain implicit Trinitarianism by affirming unity, distinction, eternal pre-existence and economic subordination in the Godhead. Studies of early Trinitarian terminology must look beyond explicit descriptions of the Godhead. They must consider also broad patterns of implicit Trinitarianism.
\end{abstract}

\section{Introduction}

Older concepts of the Trinitarianism of the second-century apologist, Theophilus of Antioch, have been challenged of late. This is significant, since he has often been considered the first Christian to use Trinitarian terminology. ${ }^{1}$ These older concepts assert that when Theophilus writes that God, his Logos, and his Sophia are types of a triad ( $\tau \rho \alpha^{\prime} \varsigma$ ), he is making the earliest terminological reference (c. 180) to the Trinity. ${ }^{2}$ J. N. D. Kelly represents this older perspective when he

1 For example, E. Venables, 'Theophilus (4)' in Dictionary of Christian Biography (London: Murray, 1911; repr., Peabody, MA: Hendrickson, 1994): 982.

2 Theophilus, Autol., 2.15. On the date of Ad Autolycum, Harnack estimates c. AD 180 as an upper limit for the final letter, since the last emperor it lists is Marcus Aurelius who died in that year. While Erbes argues for a third-century date, claiming that Theophilus did not intend to record recent historical events but only important ones, this is not borne out by the amount of trivial historical information included, nor by his argument about history. See C. Erbes, 'Die Lebenszeit des Hippolytus nebst der des Theophilus von Antiochien', Jahrbücher für protestantische Theologie 14 [1888]: 
writes, 'In spite of his tendency to blur the distinction between the Word and the Spirit, he really had the idea of the holy Triad fixed firmly in his mind.' ${ }^{3}$ Some more recent studies have both nuanced and challenged this older assessment. For example, when Nicole ZeegersVander Vorst describes Theophilus' doctrine of the Sophia of God as Stoic, she does not also show how his Sophia doctrine relates to preNicene Trinitarian thought. ${ }^{4}$ Rick Rogers explicitly denies Trinitarianism in Theophilus' writings. He asserts concerning Theophilus, 'He is not trinitarian or intentionally the initiator of trinitarian ideas.' 5

Our goal here is to affirm certain insights surfaced by such newer views while at the same time adding nuance to them in light of the historical setting of the second-century apologists. We shall see that while Theophilus makes expressions about God that may lack some of the explicit detail of later Nicene statements, he nevertheless evidences an implicit though not explicit sense of the Trinity.

It is somewhat simplistic to assert that Trinitarian belief only exists explicitly, beginning at Nicaea. Historians of doctrine and patristics scholars should notice the support within the New Testament studies guild for non-explicit Trinitarian belief. For example, Hurtado argues that the earliest expressions of Christian devotion show that, from the very earliest period, rather than as a later gradual development in Christianity, the movement was neither unitarian nor ditheistic, but binitarian. ${ }^{6}$ This binitarianism existed in the face of pressures in the religious environment which would actually work against any evolution towards it. The relevant point here is that this insight emerges not by examining explicit early Christian writings about the Godhead, but rather by implication, on the basis of early worship practices.

630-31; Adolf von Harnack, 'Theophilus von Antiochien und das Neue Testament', ZKG 11 (1890): 1-21. Unless noted, quotations of Ad Autolycum are taken from R. M. Grant, ed., Theophilus of Antioch. Ad Autolycum (Oxford: Clarendon, 1970).

3 J. N. D. Kelly, Early Christian Doctrines, (rev. edn; New York: HarperCollins, 1978): 104.

4 N. Zeegers-Vander Vorst, 'La création de l'homme (Gen. 1, 26) chez Théophile d'Antioche', Vigiliae Christianae 30 (1976): 259.

5 Rick Rogers, Theophilus of Antioch: The Life and Thought of a Second-Century Bishop (Lanham, MD: Lexington, 2000): 78-79.

6 Larry W. Hurtado, At the Origins of Christian Worship: The Context and Character of Earliest Christian Devotion (Grand Rapids: Eerdmans, 2000). Hurtado here develops and responds to challenges to his One God, One Lord: Early Christian Devotion and Ancient Jewish Monotheism (Philadelphia: Fortress, 1988; repr. Edinburgh: T\&T Clark, 1998). 
Likewise, Gordon Fee argues that just because the New Testament writers do not express the highly detailed and explicit Trinitarianism of later writers, this does not mean that they did not hold an implicit awareness of the Trinity, this awareness being sustained by their Christian experience. ${ }^{7}$ Fee marshals a wealth of New Testament support for his argument.

Similarly, David S. Yeago argues in his essay on the relationship between the New Testament and Nicene dogma that implicit Trinitarian belief is visible not in the formal doctrines of New Testament Christians, but rather, in their recorded worship practices, as well as in their acceptance of the strict monotheism of the Hebrew Scriptures. ${ }^{8}$ They not only believed that there is only one true God, but also that both Jesus and his heavenly Father are worthy of worship. Like Hurtado, Yeago is aware of recent scholarship that denies genuine binitarianism or Trinitarianism in the earliest Christian community, such as James D. G. Dunn's Christology in the Making. Like Hurtado, Yeago interacts with Dunn at crucial points by way of response.

What Hurtado, Fee, and Yeago argue is that while the earliest Christians did not possess the explicit Trinitarianism of Nicaea and Constantinople, they often conformed to a pattern of implicit Trinitarianism, or at least, binitarianism. While this pattern was by no means universal in the Second Century, as both Walter Bauer and his critic H. E. W. Turner would agree, it indeed existed in various important quarters, and in a particular second-century shape with certain distinctive features. ${ }^{9}$ Only in light of this particular secondcentury pattern of implicit Trinitarianism can one accurately appreciate Theophilus' statements about God.

7 Gordon D. Fee, 'Paul and the Trinity: The Experience of Christ and the Spirit for Paul's Understanding of God' in The Trinity: An Interdisciplinary Symposium on the Trinity, ed. Stephen T. Davis, Daniel Kendall, and Gerald O'Collins (New York: Oxford University Press, 1999): 54.

8 David S. Yeago, 'The New Testament and the Nicene Dogma: A Contribution to the Recovery of Theological Exegesis' in The Theological Interpretation of Scripture, ed. Stephen E. Fowl (Oxford: Blackwell, 1997): 89-100.

9 H. E. W. Turner challenges Walter Bauer's thesis in detail. However, he does appreciate Bauer's critique of the older view that saw earliest Christianity as a uniform monolith (Strecker and Kraft's appendix on the reception of Bauer's thesis, in Walter Bauer, Orthodoxy and Heresy in Earliest Christianity [2nd German edn; Philadelphia: Fortress, 1971; tr. by Robert A. Kraft, et al]: 297-301). 
A brief survey of two fairly contemporary apologists, Justin and Athenagoras, now follows so as to illustrate important features of this pattern. This sets the stage for observations concerning Theophilus.

\section{Contemporary Expressions}

\section{Justin Martyr}

Justin (d. AD 163-167) affirms that God is one. His God is the only true God. Also, God is transcendent, being unchangeable and eternal, entirely different from created things which are changeable and timebound. ${ }^{10}$

Justin in his Dialogue identifies the Logos with the Sophia of God. ${ }^{11}$ Theophilus only sometimes does so. Justin identifies the Logos also with the Spirit of God, both in the First Apology and in the Dialogue. ${ }^{12}$

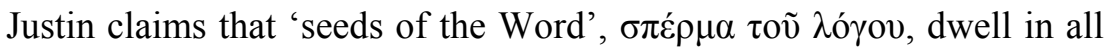
people, giving them something of the truth. ${ }^{13}$ This is typically taken as an appropriation by Justin of the corresponding Stoic doctrine. However, Edwards argues that Justin draws from Matthew 13:3-23, Luke 8:5-15, and James 1:21 to express a distinctly Christian

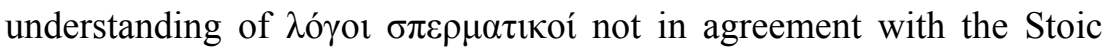
and middle Platonic understanding, but in opposition to it. ${ }^{14}$ Justin further claims that the Logos is incarnated only in the historical Christ. ${ }^{15}$

Justin, like Theophilus, affirms that the Son is the Logos, who is both immanent in God and expressed by him. He sees the Logos of God to be similar to the logoi of speaking humans: '[It is] just as we see happening among ourselves: for when we give out some word, we beget the word; yet not by abscission, so as to lessen the word [which remains] in us'. ${ }^{16}$ His point is that the Logos is begotten through the

10 Justin Martyr, 1 Apol. 13.

11 Justin, Dial,. 61.

12 Justin, 1 Apol,. 33; Justin, Dial. 61.

13 Justin, 2 Apol. 8, cf. 13; Justin, Dial. 61.

14 M. J. Edwards, 'Justin's Logos and the Word of God', Journal of Early Christian Studies 3, no. 3 (1995): 270-78.

15 Justin, Dial. 61.

16 Justin, Dial. 61. English quotations of Justin are from the Ante-Nicene Fathers translation. Greek critical editions consulted are Goodspeed's 1915 editions, accessed 
will of the Father but at the same time is always with the Father and therefore is eternally existent, a point he makes explicitly. ${ }^{17}$ In Dial. 128, he refers back to his 'expressed Logos' analogy in chapter 61. He denies that by this analogy he was referring the Hellenistic Jewish concept of 'Powers of God' which go forth and return but are inseparable from the Father. Rather, the begotten Logos is 'indeed something numerically distinct' from the Father. ${ }^{18}$

Justin understands the Logos to have helped the Father at the creation. Yet, this is merely economic subordination, since Justin holds the Logos to be eternally pre-existent, and also calls him God. ${ }^{19} \mathrm{He}$ affirms subordination in economic order and speaks of divinity in connection to the Son. Specifically, he argues that Christians hold the Son in the second place to the Father and the Holy Spirit in the third place. ${ }^{20}$ Nonetheless, he asserts that the Father and the Son are distinct from one another, but at the same time, are both God. ${ }^{21}$

\section{Athenagoras of Athens}

Athenagoras speaks about God in ways somewhat similar to Justin. He claims (c. AD 177) that there is only one God.22 God is also transcendent, above creation, being 'unbegotten, eternal, invisible, suffering nothing, comprehended by none, circumscribed by none, apprehended by mind and reason alone'. ${ }^{23}$ Therefore, he explains that Christians are 'drawing distinctions between God and matter and their respective substances'. ${ }^{24} \mathrm{He}$ thus distinguishes God from the Logos of

via Thesaurus Linguae Graecae (TLG), copyrighted by TLG and the Regents of the University of California.

17 Justin, Dial. 48.

18 For the Hellenistic Jewish idea that the Pneuma and the Sophia are the 'Two Powers' of God, see Robert M. Grant, After the New Testament (Philadelphia: Fortress, 1967): 149.

19 Cf. L. W. Barnard, 'God, Logos, the Spirit and the Trinity in the Theology of Athenagoras', Studia Theologica 24 (1970): 80-81; Justin, 1 Apol. 64 ('The Word of Wisdom, who is himself this God begotten of the Father of all things, and Word, and Wisdom, and Power, and the Glory of the Begetter'); 2 Apol. 6; Dial. 61, 62, 84, 128, 129.

20 Justin, 1 Apol. 13.

21 Justin, 1 Apol. 63.

22 Athenagoras, Leg. 10, 24.

23 Athenagoras, Leg. 10. English quotations of Athenagoras are from the Ancient Christian Writers translation. Greek critical editions consulted are Schoedel's 1972 editions, accessed via Thesaurus Linguae Graecae (TLG), copyrighted by TLG and the Regents of the University of California.

24 Athenagoras, Leg. 24. 
Stoicism which being the energiser and shaper of matter is nevertheless a material entity. ${ }^{25}$ This is an important distinction since Athenagoras is content to agree with the philosophers on other points. For example, he agrees with Plato that God is uncreated and is 'creator of all things', agrees with Aristotle that God is the unmoved mover, and agrees with the Stoics that there are, under God, seminal principles which providentially govern the universe. ${ }^{26}$ Like other apologists, Athenagoras typically accepts only those elements of contemporary philosophy which serve his apologetic and theological purposes. Justin similarly subjugates philosophy under theology. ${ }^{27}$

Athenagoras believes that the Father and the Son are each distinct and yet united as one God. This is possible because the Son is distinguished from God by being an effluence. Yet, the Son is no mere created product since he has eternal existence, and is worshipped as God, along with the Father. The Son is both in God, unified with him by the Spirit, but also proceeding ( $\pi \rho \circ \varepsilon \varepsilon \chi 0 \mu \alpha \imath)$ from him. ${ }^{28}$ Similarly,

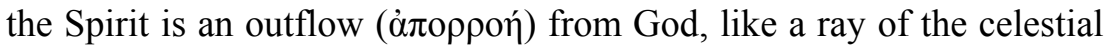
sun. Athenagoras uses the metaphor of the ray of the sun for the Spirit where Justin had used it for the Logos. ${ }^{29}$

Athenagoras affirms both the eternal pre-existence of God, his Logos, and his Spirit, as well as their unity. Christians believe that God is the Creator of all, creating the world by the agency of his Logos, and maintaining it by his Spirit. Their God, who is Father, Son, and Holy

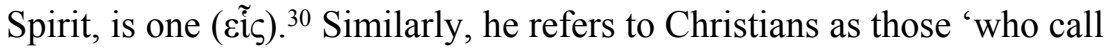
God Father and Son and Holy Spirit, proclaiming their power in unity and in rank their diversity'. ${ }^{31}$ Where in the language of Justin, the Logos is subordinate to the Father being in the second place, in the words of Athenagoras, there is a distinction in order, $\tau \alpha \dot{\xi} \xi 1 \zeta$, but also a

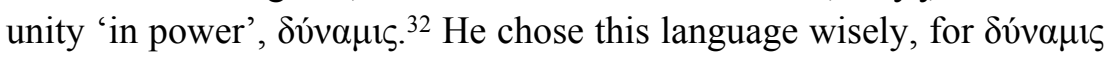

\footnotetext{
Kelly, Doctrines, 17-18.

Athenagoras, Leg. 10, 16.

Edwards, 'Justin's Logos', 261-80.

Athenagoras, Leg. 10.

Justin, Dial. 128.

30 Athenagoras, Leg. 10, 24.

31 Athenagoras, Leg. 10.5.

32 Justin, 1 Apol. 13.
} 
and $\tau \dot{\alpha} \xi_{1 \zeta}$ were sometimes used by the Greek poets and philosophers to clarify the relationship between Zeus and lesser gods. ${ }^{33}$

These affirmations appear in his larger argument that Christians cannot be atheists for not believing in the Greek gods. Indeed, Christians affirm much the same as Greek religionists. He surveys the philosophers in Leg. 6, showing that Philolaus, Lysis, Opsismus, the Pythagoreans, Plato, Aristotle, and the Stoics all teach that God is one, even though they may recognise lesser, created gods through whom he works, or call him by different names in particular spheres of his activity.

The idea of deities' being unified under the monarchy of a supreme god was not foreign to Greek religion. Philosophers of Athenagoras' day, such as Maximus of Tyre, held that the many gods were united in administering the rule of a supreme god. ${ }^{34}$ Schoedel shows that this Trinitarian development in Athenagoras arises in response to accusations from Greek religionists. ${ }^{35}$ Athenagoras is intent strictly on answering the charge that Christians are atheists. He answers first, that Christians are not atheists since they are monotheists, hence his emphasis on the unity of God. Second, Christians are not atheists because of their belief in the multiplicity of the Godhead. If Greek polytheists are not atheists, then neither are Christians, who are akin not only to the strict monotheists, but also to the polytheists.

However, Athenagoras is not driven to these concepts strictly by philosophy, for it is only a lesser revelation compared to the voice of the prophets. He writes, 'one might consider our account of the matter to be true humanism. But the voice of the prophets guarantees our reasoning besides.' He then proceeds to give biblical proofs for the unity of God. ${ }^{36}$

Like most of the apologists except for Justin, Athenagoras hardly makes any mention of the historical Christ. ${ }^{37}$ This does not imply however that these apologists did not consider the historical Christ important. Such silences were merely apologetic manoeuvres. ${ }^{38}$

33 William R. Schoedel, 'A Neglected Motive for Second-Century Trinitarianism', Journal of Theological Studies N. S. 30, Pt. 2 (1980): 364.

34 Barnard, 'Theology of Athenagoras', 70-72.

35 Schoedel, 'Neglected Motive', 356-67.

36 Athenagoras, Leg. 9.

37 His only reference is in Leg. 21, where he raises the idea of a god taking on flesh.

38 Athenagoras and Theophilus are similarly silent concerning the historical Christ. For the meagre Christology in Ad Autolycum owing to its protreptic genre, see 


\section{Trinitarian Perceptions by Theophilus of Antioch}

While not denying genuine differences, one is nevertheless struck by similarities between Theophilus' descriptions of God and those of Justin and Athenagoras. Like both Justin and Athenagoras, Theophilus affirms that God is one, the Lord of all, the only true God, Creator, and Sustainer embracing all things. ${ }^{39}$ Also like Justin and Athenagoras, he holds that God is transcendent, wholly other than creation. He writes, 'For he who is created has needs, but he who is uncreated [that is, God] lacks nothing.' 40

Theophilus is also similar to Justin in regard to the relation between God and his Logos. He asserts that the Logos is both innate

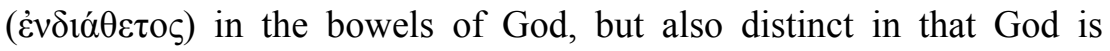
'discharging [him] out' ( $\dot{\varepsilon} \xi \varepsilon \rho \varepsilon v \xi \alpha \dot{\alpha} \mu \varepsilon v o \varsigma) .{ }^{41}$ This is not unlike Justin's point that the Logos is both in God and begotten of him. Both apologists further assert that God begot the Logos before the Creation, so that he might assist in it. ${ }^{42}$ Furthermore, both apologists call him the 'beginning/first cause/authority' ( $\alpha \rho \chi \eta)$ ). ${ }^{43}$ Theophilus explains that the Logos is called $\alpha \rho \chi \eta ́$ because he leads and guides the creation of the universe.

In his discussion of Genesis 3, Theophilus explicitly distinguishes God/Father from Logos/Son. ${ }^{44}$ While God does not become localised, since he is everywhere, his Son may indeed appear locally, walking and talking in theophany. With this in mind, Theophilus interprets Genesis 3:8-19 in a distinctly Christian way, reading the passage in light of New Testament passages such as John 1:1; 1 Corinthians 1:24; Colossians 1:15.

J. Bentivegna, 'A Christianity without Christ by Theophilus of Antioch' in Papers Presented to the Sixth International Conference on Patristic Studies Held in Oxford, 1971, ed. Elizabeth A. Livingstone (StPatr 13; Berlin: Akademie-Verlag, 1975): 107130; Deirdre Good, 'Rhetoric and Wisdom in Theophilus of Antioch', Anglican Theological Review 73, no. 3 (1991): 323-30; Rogers, Theophilus, 4-26.

39 Theophilus, Autol. 3.9; Ferdinando Bergamelli, 'On the Meaning of the Term Pantokrator in Theophilus of Antioch' in Papers of the 1983 Oxford Patristics Conference, ed. Elizabeth A. Livingstone (StPatr 18 no. 3; Kalamazoo; Leuven: Cistercian; Peeters, 1989): 71-83.

40 Theophilus, Autol. 2.10.

41 References in this paragraph are to Theophilus, Autol. 2.10. Cf. 2.22. I have amended the translation of $\dot{\varepsilon} \xi \varepsilon \rho \varepsilon v \xi \dot{\alpha} \mu \varepsilon \varepsilon \nu$.

42 Justin, Dial. 61; Theophilus, Autol. 2.10, 22.

43 Justin, Dial. 61; Theophilus, Autol. 2.10, 22.

44 Theophilus, Autol. 2.22. 
Theophilus knows that the Logos is eternally pre-existent since God's Logos is always innate in the heart of God and constantly speaks with him. ${ }^{45} \mathrm{He}$ is similar also to Athenagoras when he asserts that there are two who emanate from God, the Logos and the Pneuma in the case of Athenagoras, and the Logos and the Sofia in the case of Theophilus. With such expressions, Justin, Athenagoras, and Theophilus, in certainly differing degrees, nevertheless all imply that unity, distinction, eternal pre-existence, and economic subordination are descriptors of the Christian God.

By his use of $\tau$ prós, Theophilus is the only apologist to use any term of 'threeness' to refer to God. Neither do the apostolic fathers use any such term. Theophilus is the first. ${ }^{46}$

He asserts that God creates humanity through the agency of his Logos and his Sophia, who are his 'hands'. ${ }^{47}$ Irenaeus would later borrow this figure from Theophilus. ${ }^{48}$ However, Irenaeus would also explicitly add several times that the Logos is Christ and the Sophia is the Holy Spirit. 49

Theophilus does not invent his language about God's hands. Rather, he sees it in rabbinic commentaries. Anthropomorphic descriptions of God in the Hebrew Scriptures were looked down upon in the Hellenistic world. For this reason, Hellenistic Jews explained them using the Greek idea that God used collaborators as instruments of creation. ${ }^{50}$ However, when Christians used this teaching to argue for the divinity of Christ, or for the activity of God, his Logos, and his Spirit, as did Irenaeus, the rabbis of Palestine quickly rejected what their tradition had formerly embraced. An example of such rejection is

\footnotetext{
45 Theophilus, Autol. 2.22.

46 Theophilus, Autol. 2.15.

47 Theophilus, Autol. 2.18; cf. 1.4-5; 2.10, 35.

48 Loofs shows the heavy influence of Theophilus on Irenaeus, even if Loofs' characterisation of Irenaeus as a theologian has not been widely accepted. See Friedrich Loofs, Theophilus von Antiochen Adversus Marcionem und die Anderen Theologischen Quellen bei Irenaeus (Texte und Untersuchungen zur Geschichte der altchristlichen Literatur, vol. 46, no. 2 ; 4. Reihe, vol. 1, no. 2; Leipzig: J. C. Hinrichs, 1930). For reactions to Loofs' thesis, see F. R. M. Hitchcock, 'Loof's Theory of Theophilus of Antioch as a Source of Irenaeus', Journal of Theological Studies 38 (1937): 130-39; 255-66; Adelin Rousseau, 'Plan du livre v' in Irenaeus. Contre les hérésies, livre 5, ed. Adelin Rousseau, Louis Doutreleau, and Charles Mercier (Sources chrétiennes; Paris: Les Editions du Cerf, 1969): 166-91.

49 Irenaeus, Haer. $4.7 .4 ; 4.20 .1 ; 4.20 .3$. Theophilus never equates the Sophia to the Spirit, except in 2.10 where he equates Logos, Spirit, and Sophia.

50 Grant, After the New Testament, 149.
} 
reflected in the speech of Trypho the Jew in Justin's Dialogue. ${ }^{51}$ While Theophilus may not know Philo, he knows other Jewish commentaries. ${ }^{52}$ Philo referred to Sophia as the hand of God in Genesis 1:26 prior to Theophilus, ${ }^{53}$ and likely is not the only Jewish commentator to do so. However, Theophilus adds the Logos to the divine conversation in Genesis 1:26. He differs from the rabbis by adding the Logos, and he differs from other Christian writers by including the Sophia. Thus, he extends rabbinic exegesis in a Christian manner by including the Logos, but also remains faithful to Jewish interpretative traditions of the passage by retaining the Sophia. Nicole Zeegers-Vander Vorst, who helpfully exposes this extension of Jewish interpretative tradition by Theophilus, explains that he makes these extensions in order to refute polytheistic interpretations of the verse. ${ }^{54}$

However, while Zeegers-Vander Vorst is correct in asserting that Theophilus is Stoic concerning God's Sophia, since for him, Sofia is not Pneuma, one must not think that his ideas about God are merely Stoic. ${ }^{55}$ Admittedly, his is certainly not Nicene Trinitarianism, since he does not speak of co-equal, co-essential, divine Persons. Nevertheless, his Sophia language can neither be exclusively Stoic, since his larger concept of a God/Logos/Sophia triad is so similar to the thought of his Christian contemporaries, Justin and Athenagoras, in regard to unity, distinction, eternal pre-existence, and economic subordination. These similarities appear because these apologists reflect apostolic preaching and liturgical traditions in the pre-Nicene church. Indeed, ZeegersVander Vorst's larger point is that Theophilus 'Christianises' some Jewish interpretations of Genesis 1:26. The point here is that when Theophilus appropriates some Stoic concepts, he fits them into a conceptual framework typical of pre-Nicene Trinitarianism. Therefore, this is 'Christianised' Stoicism.

Rogers argues that Theophilus simply uses his figure of the hands of God by way of personification language to explain how the

\footnotetext{
51 Justin, Dial. 62.

52 Robert M. Grant, Greek Apologists of the Second Century (Philadelphia: Westminster, 1988): 157-59.

53 Grant, Greek Apologists, 169.

54 Nicole Zeegers, 'Les trois cultures de Théophile d'Antioch' in Les apologistes chrétiens et la culture grecque, ed. Bernard Pouderon and Joseph Doré (Théologie historique; Paris: Beauchesne, 1997): 150-51.

55 Zeegers-Vander Vorst, 'La création de l'homme', 259.
} 
unknowable God can be known through his acts of creation. ${ }^{56}$ Rogers asserts that $\tau$ có́ Sophia, which are all transcendent, just as their types, the first three days of the creation, all frame the creation of things not requiring light. ${ }^{57}$ His point is that Theophilus does not mean to explain the Godhead, but simply wants to address the problem of divine transcendence. ${ }^{58} \mathrm{He}$ explicitly disassociates Theophilus from any kind of Trinitarianism, asserting, 'He is not trinitarian or intentionally the initiator of trinitarian ideas. ${ }^{59}$ Again, he emphasises, 'one should not read any trinitarian dogma into Theophilus' thought regarding the hands of God'. ${ }^{60}$

The discussion by Rogers is helpful for understanding the rhetorical structure of Ad Autolycum. Furthermore, he is right in claiming that Theophilus does not initiate Trinitarianism, and in that his term $\tau$ ctós indeed is part of a discussion of transcendence, and not of the Godhead per se. However, an additional point must also be kept in mind while acknowledging these insights. Cannot early Trinitarianism, even if it is merely implicit, inform Theophilus' terminology? He wants Autolycus to realise that Christianity is the true religion. Therefore, it is not

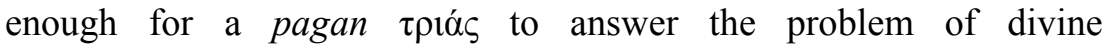
transcendence. He does not want it to go unnoticed that only this particular $\tau$ plós solves the problem. See especially his discussion of Genesis 3 where he distinguishes between Father and Logos, but also calls the Logos 'God' and the Father 'God'. ${ }^{61}$ This weighs alongside his strong emphasis on monotheism, especially in book three: 'We acknowledge a god, but only one.' 62

The term $\tau$ plás, then, reflects an implicit Trinitarianism that is not unknown in the Second Century, not only because Theophilus is so much like Justin and Athenagoras in perceiving unity, distinction, eternal pre-existence, and economic subordination in God, as argued above, but also because he takes care to 'Christianise' traditional rabbinic interpretations of Genesis 1:26, making them more triune, as

\footnotetext{
56 Rogers, Theophilus, 78-79.

57 Theophilus, Autol. 2.15.

58 Rogers, Theophilus, 79.

59 Rogers, Theophilus, 78.

60 Rogers, Theophilus, 79.

61 Theophilus, Autol. 2.22.

62 Theophilus, Autol. 3.9.
} 
Zeegers-Vander Vorst has shown. Although Theophilus certainly is not 'intentionally the initiator of Trinitarian ideas', this does not mean that his use of $\tau \rho$ ió has no Trinitarian connection whatsoever. Theophilus' $\tau \rho t \alpha ́ s$ may indeed retain its status as the earliest Trinitarian term, since it grows from the soil of a particular second-century Trinitarianism typically expressed not so much explicitly as through implication. 